\title{
Relationship between Biology Teacher Teaching Style with Students Learning Outcome
}

\author{
Winda Zuwanna Zufri \\ Student of Postgraduate Biology Education \\ State University of Medan \\ Medan, Indonesia
}

\author{
Herbert Sipahutar \\ Lecture of Postgraduate Biology Education \\ State University of Medan \\ Medan, Indonesia
}

\author{
Syahmi Edi \\ Lecture of Postgraduate Biology Education \\ State University of Medan \\ Medan, Indonesia
}

\begin{abstract}
Teaching style was very varied and required in learning. Teaching style considered important in improving students learning outcome. A teacher should be creative and critical in teaching style to produce conducive classroom situation. Monotonous learning environment could reduce student's interest in doing learning in classroom that later could affect in reducing student's learning outcome. Further, teaching style also could affect in improving learning outcome. This research was correlational descriptive research to find out relationship between teacher's teaching styles with second grader students biology learning outcome in Madrasah Aliyah Negeri 1 Medan. Quantitative method was used as approach, data of students daily test scores was collected and analyzed, teaching style data was collected through questionnaire. Research result found out teachers teaching style in biology lesson was good with interval distribution was 80-90 ( $>70)$. Distribution of Biology learning outcomes of second grader students MAN 1 Medan academic year is classified as good, with a general score distribution $\mathbf{2 0}$. There is a significant and strong relationship between biology teacher teaching style with student's Biology learning outcomes $(r=0.690 ; p=0.000)$.
\end{abstract}

\section{Keywords-Teaching style, Learning outcome, Correlasional}

\section{INTRODUCTION}

Education has a very strategic role in improving quality of Indonesian's human resources and efforts in realizing public welfare and educating the life of the nation. The low quality of education at every education's level and unit is one of the educational problems currently faced by Indonesian people. Various efforts have been made to improve the quality of national education.

Education is all learning experiences that take place in the environment and throughout life. Education is basically a transfer of values and knowledge that affects individuals, to change the behavior and attitudes of someone who does not know to know, from wrong to being right and from bad to be good. In order to get this knowledge each individual has a way of accepting or understanding the lesson that we called as learning style. Basically, every person is created differently, so the way of learning is certainly not the same. Let alone in same one lineage, even twins are different in strength, ability or certain characters [1].
A teacher must be able to adjust a learning system with a teaching style that attracts and engages students actively. Teacher's teaching style is a teacher's technique in delivering materials adjusting the objectives and nature of certain subjects, student motivation, classroom management and learning evaluation. Different teachers make different teaching style even though all have same goal to convey knowledge, shaping student attitudes, and making students skilled in working. Teaching according to [2] is guiding student learning activities, managing and organizing the environment around students so that it can encourage students to do learning activities.

Teacher's teaching style according to Conti [3] is grouped into 2 types of approaches, teacher centered and student centered approaches. Both approaches have advantages and disadvantages when applied in learning process. Teacher's approach in teaching will be effective if it is aligned with the objectives, subject matter, interests and student's needs, whether it is done in group or individual teaching.

The main task of teachers in learning is teaching. Winkel (1996) defined teaching as a typical teacher-specific behavior and which is somewhat permanent in every teaching. [4] defined teaching as a teacher's effort to convey and impart knowledge to students, or tend to be a "transfer of knowledge". In practice of learning, teaching behaviors shown by teachers are diverse, although they mean the same. The variety of teachers' teaching behaviors when traced will show a general pattern of interaction between the teacher, content or subject matter and student. This pattern then by Dianne Lapp and team termed as teaching style [5].

In order to make it easier to choose the right and preferred style in teaching, it is better for teacher to know about student's learning patterns. Student's attention is crucial in teaching and learning process, with it education goal will be achieved. There are many factors that influence student's attention in learning, for example teacher explanation is wrong, not focus or difficult to understand, no variation in teaching, and so on. Therefore, the teachers should pay more attention to their teaching style. This is done to see the effectiveness of the teacher's attitude and teaching style so that student's attention will increase in following the learning given. By good attention, the knowledge delivered by teacher 
will be absorbed by the students. However, there are so many students who do not have ability to focus, their low motivation in learning may take part in this case. One of the causes found based on observations to several public and private schools in Medan City showed this case was generally caused by teacher's attitude and teaching style not in accordance with the wishes of students. The better and quality of the style displayed when teaching, of course will motivates students to participate in the learning.

Talking about teacher's teaching style and strategies, nowadays there are many innovations and new things to be done to encourage formation of a conducive learning environment. The environment is very influential for students because it could promote creative-productive activities. Teaching style that a teacher has also will affect student learning. The less preferred teaching styles for students will likely influence students learning styles. The less preferred teaching style can occur because teacher lacks in preparation and subject matter mastery, therefore teacher will deliver ambiguous information to students. As a result of this ambiguity, students become lazy to learn. Teacher who have been teaching for a long time, usually teach only by the lecture method without any new innovations that can support student's enthusiasm. This has an impact on student's learning attitudes, students tend to become bored, sleepy, passives and just taking a notes. Progressive teachers dare to try new methods and styles, which can help improve the quality of the teaching and learning process, and increase student's motivation to learn. In order to produce good teaching and learning outcomes, the teacher must have the ability to teach outstanding. This indicates clearly that the style used and displayed by the teacher has a major contribution to the quality of student learning styles to participate in learning activities.

\section{RESEARCH METHODS}

\section{A. Location, Time, Population and Sample}

This research was conducted at Madrasah Aliyah Negeri (MAN) 1 Medan at Jl. Willem Iskandar No. 7B Medan, North Sumatra. This research was conducted in second semester in academic year 2017/2018, started from November 2017 until May 2018. The populations in this study were four Biology teachers and all second grader students (350 students) of Madrasah Aliyah Negeri 1 Medan in academic year 2017/2018. The study samples were two, distinguished by a sample of teachers involved in the teaching style variable, and students involved in measuring learning outcomes.

\section{B. Research Types and Design}

This study used a quantitative approach with descriptive correlational research methods. The data obtained in each research variable was ex-postfacto. Research variables were a series of independent variables (predictors) which has occurred when researchers began conducting research (teaching style) and dependent variables (student learning outcomes)

\section{Research Instruments}

Teacher's teaching style data was collected using questionnaire. The questionnaire was arranged in the form of questions with 5 (five) alternative answers with scoring system that were determined based on the Likert scale (1 - 5).

\section{RESULTS AND DISCUSSION}

\section{A. Results}

The measurement result of second grader Biology teachers teaching style in MAN 1 Medan academic year 2017/2018, was in the range of $68.6-89.7$ with an average value of $80.2 \pm$ 4.8. The largest distribution was obtained at intervals of 80-89, followed by intervals of 70-79. Only $1.6 \%$ of the distribution was obtained at intervals of 60-69 (Figure 1).

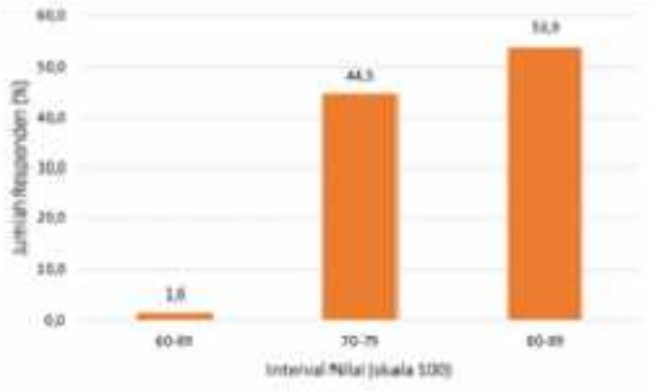

Figure 1. Data score distribution of second grader Biology teachers teaching style in MAN 1 Medan academic year 2017/2018

The distribution of Biology learning outcomes of second grader students of MAN 1 Medan academic year 2017/2018, was in the range of $76.0-96.2$ with an average value of $87.0 \pm$ 4.4. The largest distribution was obtained at intervals of 80-89, followed by intervals of 90-99 and 70-79 (Figure 2).

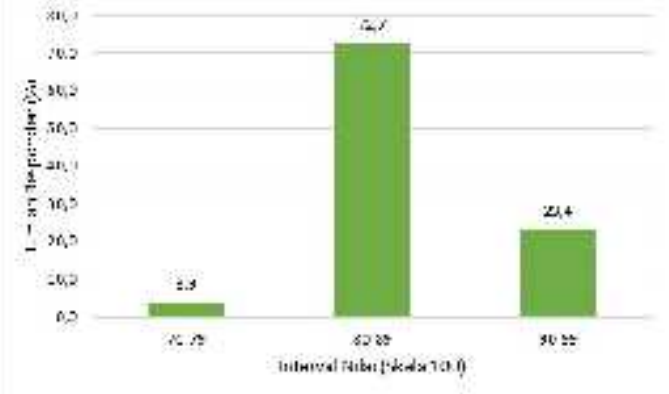

Figure 2. Biology learning outcome distribution data of second grader student in MAN 1 Medan academic year 2017/2018

\section{a. Relation between teacher's Teaching Style and student's biology learning outcome}

Regression test results of teaching style and biology learning outcome obtained the value of $r=0,690$, indicating strong relationship between variables. Further analysis show the value of $\mathrm{F}=231,305 ; \mathrm{P}=0,000$, indicating significant relationship between variables. Therefore, the analysis accepted hypothesis alternative (Ha), concluding there was a significant relationship between teaching style and Biology learning outcomes of second grader students in MAN 1 Medan academic year 2017/2018. 
The results of the regression coefficient between teaching style variable and biology learning outcomes was 0.629 with constant value (a) was 36,550 and regression equation obtained was $\hat{\mathrm{Y}}=\mathrm{a}+\mathrm{bX}$, then $\hat{\mathrm{Y}}: 36,550+0,629 \mathrm{X}$. This means that teachers get teaching style and students have biology learning outcomes of 36,550 and as teaching style increase, student learning outcomes increase by 0,629 . The result of correlation coefficient $\left(\mathrm{R}^{2} \mathrm{x}_{2} \mathrm{y}\right)$ was 0.477 , which means contribution of teaching style to biology learning outcomes was $47.7 \%$. The data can be seen in figure below

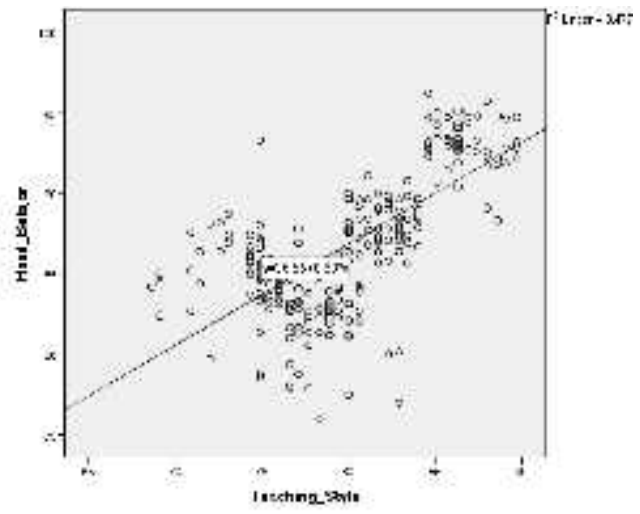

Figure 3. Teacher's Teaching Style Relationship with Student Biology Learning Outcomes $\left(\hat{\mathrm{Y}}=36,550+0,629, \mathrm{R}_{\mathrm{x} 2 \mathrm{y}}^{2}=0,477\right)$

\section{B. Discussion}

\section{a. Teacher's Teaching Style in Biology lesson}

Result of research in MAN 1 Medan shown the average score of teachers teaching style was 80,17 . This could also means teachers teaching style in MAN 1 Medan was categorized as high in teaching style. Selection of one particular learning method will affect the suitability type of learning media used. Edgar Dale views the value of learning media in learning is classified based on learning experience from the most concrete level to the most abstract, commonly known as cone of experience. The highest level of experience is the most concrete experience. While the lowest one is the most abstract [7]. The study results by [8] stated that student learning outcomes are influenced by teacher factors and teaching activities.

Teachers who are able to understand the wishes of students will find it easier to establish familiarity with their students. A good teacher is a teacher who tries to pay attention to his/her students. This is in line with [9], that student's perceptions of teacher support make them feel cared and assisted by teacher. Teacher attention encourages students to fulfilled teacher expectations. When students feel they get emotional support from their teacher, they likely will be more involved in their academic work, including by increasing their learning efforts.

\section{b. Student's learning outcome}

Data analysis showed second grader students Biology learning outcome in second semester academic year $2017 / 2018$ was 86,98 . The score indicates students have high learning outcome.

Learning outcomes are abilities possessed by students after students receive learning experiences, both in the form of cognitive, affective and psychomotor aspects [10]. Factors that influence cognitive learning outcomes are very complex involving internal and external factors, such as: interest, motivation, attitude, intelligence (intelligence), learning environment, learning strategy, physical condition and others. Djamarah (2011) argued learning outcomes are influenced by several factors including: (1) Environment; (2) Instrumental; (3) Physiological conditions; and (4) Psychological conditions. Further, learning outcomes are formulated as a mental or psychological activity, which takes place in active interactions with the environment, which results in changes in the value of understanding, skills and attitudes [11].

\section{c. Teacher Teaching Style Relationships with Student Biology Learning Outcomes}

According to the data obtained in research, the average value of teachers teaching styles in MAN 1 Medan was 80.17 which is placed them in high category. Average score of students biology learning outcome was 86.98 which is also in high category. The $r$ value obtained was 0.690 indicates strong relationships. The contribution of the teacher's teaching style to student biology learning outcomes was $47.7 \%$. In this case there was a significant relationship between teacher's teaching style on student biology learning outcomes, where teachers teaching style were good and varied resulting positive effect on student learning outcomes. By good teaching style, students biology learning outcomes could increase because it compatible with their learning styles. This is in line with research by [12], that matching learning strategies with student's characteristics and subject matter will affect learning outcomes obtained by students.

Teaching styles are influential in guiding and directing learning process and increasing student's ability to learn. This is supported by the results of a study by [13] which shows that there is a significant influence between teacher teaching styles to student academic achievement. Further, [14] found out teacher teaching styles are the main effective factors for improving student learning outcomes.

Various types of characters and teaching styles possessed by the teacher are likely to have a strong enough influence on student learning outcomes in school and a teacher must could placed himself cleverly in the learning process. [15] argued learning process must be considered what can encourage students to learn well or think and paying attention, plan and carry out related activities or the one could support learning. This is in line with the study of [16], which stated that in a classroom a teacher has an important role in controlling and motivating students to increase student's interest in learning new things, therefore teacher must use all of his abilities for the effectiveness of learning process.

Learning styles can determine student learning outcomes. If teacher provides a strategy that fits the student's learning style, students can develop better. Therefore, it can be concluded that there is a relationship between teacher's teaching style and student's biology learning outcomes. This could occur because there are factors influenced it, such as internal factors of students themselves and factors of teachers who teach them in class, because teachers pay attention to student learning styles in the classroom, therefore it affects student's learning outcomes to be better. 
Based on the explanation, the teacher's teaching style can encourage students to achieve the expected learning outcomes, such as above average skills, achieving high learning outcomes, confident in their abilities, and tend to complete their own tasks.

Thing that can affect learning outcomes is suitable teacher teaching styles appropriate to student's learning styles in a conducive and enjoyable learning environment. The relationship of teaching style to student biology learning outcomes described above has a significant correlation between variables. Therefore, the teacher's teaching style can improve student learning outcomes.

\section{CONCLUSION}

Based on the results of the research and discussion previously described, it could be concluded that

1. Distribution of teaching style score of second grader Biology in MAN 1 Medan academic year 2017/2018 classified as good with the largest distribution at intervals of 80-90 ( $\geq 70)$.

2. Distribution of Biology learning outcomes of second grader students MAN 1 Medan academic year is classified as good, with a general score distribution 70 .

3. There was a significant and strong relationship between biology teacher teaching style with student's Biology learning outcomes $(r=0.690 ; p=0.000)$.

\section{References}

[1] Bloom dalam Thobroni.2015.Hasil Beljar.Jakarta:Bumi Aksara.

[2] Sudjana, N. 2010. Dasar-dasar Proses Belajar, Sinar Baru Bandung
[3] Ahmed, Ahmed Khaled. 2013. Teacher Centered Versus Learned Centered Teaching Style. The Journal of Global Business Management, 9(1): 22-34.

[4] Sardiman A.M. 2012. Interaksi dan Motivasi Belajar Mengajar. Jakarta: Rajawali Press.

[5] Ali, Muhammad. 2008. Guru Dalam Proses Belajar Mengajar. Bandung: Sinar Baru Algesindo. 17

[6] Djamarah, S.B. 2011. Psikologi Belajar. Jakarta: PT. Rineka Cipta.

[7] Sumiati dan Asra. 2007. Metode Pembelajaran. Bandung: Wacana Prima.

[8] Aswan Zain dan Syaiful Bahri Djamarah. 2002. Strategi Belajar Mengajar, Jakarta: Rineka Cipta

[9] Kaplan A., Patrick, H. Dan Ryan, A. M. 2007. Early Adolescents' Perception of Clasroom Social Environment, Motivational Belief, and Engangement. Journal of Educational Psychology, 99 (1): 83-89.

[10] Widayanti, F.D. 2013. Pentingnya Mengetahui Gaya Belajar Siswa dalam Kegiatan Pembelajaran di Kelas. Erudio, 2 (1): 7-21.

[11] Winkel, W.S. 2009. Psikologi Pengajaran. Yogyakarta: Media Abad.

[12] Halim, A. 2012. Pengaruh Strategi Pembelajaran dan Gaya Belajar terhadap Hasil Belajar Fisika Siswa SMPN 2 Secanggang Kabupaten Langkat. Jurnal Tabularasa PPS UNIMED, 9 (2): 1-10.

[13] Shaari, Abdull Sukor; Yusoff Nurahimah Mohd; Ghazali, Izam Mohd Osman Rafisah Hj; and Zahir, Nur Fatirah Mohd. 2014. The Relationship between Lecturers' Teaching Style and Student's Academic Engagement. Procedia-Social and Behavioral Sciences 118 (2014) 10-20.

[14] Beck, C.R. 2001. Matching Teaching Strategies To Learning Style Preferenes. The Teacher Educator, 37(1): 1 - 15.

[15] Slameto. 2015. Belajar dan Faktor-Faktor yang Mempengaruhi. Jakarta: Rineka Cipta.

[16] Zamri M., Nik Mohd R., Nik Yusoff, dan Juliawati I. 2009. The Comparison of Teaching Styles Between English and Malay Teachers. Malaysia Educational Journal. 34 (1), 67 - 92 